\title{
PERBEDAAN KEPUASAN KERJA PADA PEGAWAI OUTSOURCING DENGAN PEGAWAI TETAP PT. PLN (PERSERO)
}

\author{
Annisa N. Amrullah, Bambang S. Arifin \& Nisa Hermawati \\ Fakultas Psikologi UIN Sunan Gunung Djati Bandung, Jl. A.H Nasution No. 105 Bandung \\ email: annisa.amrullah@facebook.com
}

\begin{abstract}
Abstrak
Saat ini di bidang industri tenaga kerja muncul satu trend yang marak dibicarakan yaitu sistem outsourcing, yaitu sebuah proses mengalihdayakan atau memindahkan kegiatan usaha ke pihak ketiga. Peneliti menduga bahwa sistem ini memiliki dampak terhadap kepuasan kerja dari para karyawan. Hal ini dapat terjadi ketika karyawan merasa diperlakukan tidak adil, dengan tidak adanya tunjangan dan kesejahteraan serta diskriminasi gaji. Penelitian ini dilakukan dengan menggunakan desain penelitian komparatif, yaitu membandingkan 45 orang pegawai tetap dan 75 orang pegawai outsourcing yang bekerja di PT. PLN (PERSERO) UPJ Baleendah. Instrumen yang digunakan untuk menjaring data mengenai kepuasan kerja adalah instrumen yang dikembangkan berdasarkan teori kepuasan kerja Herzberg. Adapun uji statistik yang akan digunakan untuk menguji hipotesis yang diajukan adalah $U$ Mann Whitney. Berdasarkan hasil perhitungan yang diperoleh dengan derajat kepercayaan sebesar $95 \%(\alpha=0,05)$ diketahui bahwa $p>\alpha$. Hal ini memiliki arti bahwa Ho diterima dan H1 ditolak, sehingga dapat dikatakan bahwa tidak terdapat perbedaan kepuasan kerja yang signifikan antara pegawai outsourcing dengan pegawai tetap di PT. PLN (PERSERO) Unit Pelayanan dan Jaringan Baleendah.
\end{abstract}

Kata kunci: kepuasan kerja, pegawai, outsourcing

\begin{abstract}
Industrial employee recently faced outsourcing system, a process transfering bisnis activity to the third parties. This system will give an impact to job satisfaction of the employee if they feel unfairly treated such as no fringe benefit and discriminated salary. This comparative research design compared between 45 permanent employee and 75 outsourcing employee at PT. PLN (PERSERO) UPJ Baleendah. Instrument used is job satisfaction scales from Herzberg. Statistical analysis used U Mann Whitney to test hypothesis proposed. Result using 95\% trusted degree $(\alpha=0,05)$ found $p>\alpha$. It is concluded that Ho is accepted and $\mathrm{H} 1$ is not. Therefore, there is no significant differences between outsourcing employee and permanent employee at di PT. PLN (PERSERO).
\end{abstract}

Keywords : job satisfaction, employee, outsourcing

\section{PENDAHULUAN}

Menurut Hasibuan (2010), pegawai/ karyawan adalah makhluk sosial yang menjadi kekayaan utama bagi setiap perusahaan, menjadi perencana, pelaksana dan pengendali yang selalu berperan aktif dalam mewujudkan tujuan perusahaan. Oleh sebab itu pegawai dalam sua- tu perusahaan perlu dipertahankan keberadaannya demi kelangsungan hidup perusahaan tersebut.

Saat ini di bidang industri tenaga kerja muncul satu trend yang marak dibicarakan yaitu sistem outsourcing. Di definisikan sebagai sebuah proses mengalihdayakan atau memindahkan kegiatan usaha ke pihak ketiga. Tujuan melakukan outsourcing adalah perusahaan da- 
pat fokus terhadap core business, penghematan biaya operasional, turnover karyawan menjadi rendah, dan modernisasi dunia usaha. (Divisi Riset Manajemen; 2008).

Outsourcing terbagi atas dua suku kata yaitu out dan sourcing. Out adalah keluar dan sourcing berarti mengalihkan kerja, tanggung jawab dan keputusan kepada orang lain. Dalam dunia bisnis, outsourcing dapat diartikan sebagai penyerahan sebagian pelaksanaan pekerjaan yang sifatnya penunjang oleh suatu perusahaan kepada perusahaan lain melalui perjanjian penyediaan jasa pekerja.

Menurut Pasal 64 UUK, outsourcing adalah suatu perjanjian kerja yang dibuat antara pengusaha dengan tenaga kerja, dimana perusahaan tersebut dapat menyerahkan sebagian pelaksanaan pekerjaan kepada perusahaan lainnya melalui perjanjian pemborongan pekerjaan yang dibuat secara tertulis. Pasal 1601 b KUH Perdata yang menyatakan bahwa outsourcing disamakan dengan perjanjian pemborongan pekerjaan.

Menurut Sehat Damanik outsourcing adalah suatu perjanjian dimana pemborong mengikat diri untuk membuat suatu pekerjaan tertentu bagi pihak lain yang memborongkan dengan menerima bayaran tertentu dan pihak yang lain yang memborongkan mengikatkan diri untuk memborongkan pekerjaan kepada pihak pemborong dengan bayaran tertentu. Definisi lain yang lebih singkat bahwa outsourcing merupakan suatu tindakan membagi control manajemen dari suatu fungsi bisnis kepada supplier lain (Telkom Indonesia, 2009).

Pegawai outsourcing/kontrak adalah pegawai yang diperbantukan untuk menyelesaikan pekerjaan-pekerjaan rutin perusahaan dan tidak ada jaminan kelangsungan masa kerjanya. Sedangkan pegawai tetap adalah pegawai yang menerima atau memperoleh penghasilan dalam jumlah tertentu secara teratur dan pegawai yang bekerja berdasarkan kontrak untuk suatu jangka waktu tertentu sepanjang pegawai yang bersangkutan bekerja penuh (full time) dalam pekerjaan tersebut. (Divisi Riset Manajemen; 2008).

Beberapa ketentuan yang berlaku untuk pegawai tetap adalah sebagai berikut: a). Tidak adanya batasan jangka waktu lamanya bekerja. b). Perusahaan dapat mensyaratkan masa percobaan maksimal 3 bulan. c). Masa kerja dihitung sejak masa percobaan.d). 4. Jika terjadi pemutusan hubungan kerja bukan karena pe- langgaran berat atau pegawai mengundurkan diri maka pegawai tetap mendapatkan uang pesangon (bagi pegawai yang sudah bekerja minimal 3 Tahun) dan uang penggantian hak sesuai Undang-Undang yang berlaku.

Demonstrasi besar-besaran sering dilakukan oleh para karyawan outsourcing setiap Hari Buruh menuntut penghapusan sistem outsourcing dalam dunia pekerjaan. Para karyawan merasa diperlakukan tidak adil, tidak adanya tunjangan dan kesejahteraan karyawan serta diskriminasi gaji yang menyebabkan ketidakpuasan kerja. Efek negatif bagi perusahaan diantaranya, produksi jadi terhenti, perputaran uang terhambat, kerusakan alat-alat produksi dan kerugian yang cukup besar. (Kompas; 20 11, 3 Mei).

Sama seperti perusahaan lain, PT. PLN (PERSERO) UPJ Baleendah pun menerapkan sistem outsourcing dalam perusahaannya. Alasannya yaitu untuk membantu sebagian pekerjaan PLN dikarenakan minimnya pegawai yang hanya memiliki 45 orang pegawai tetap, jumlah pegawai outsourcing saat ini 95 orang. Dilihat dari tingkat usia pun, pegawai tetap yang berkisar antara usia 30 tahun hingga 50 tahun tentu bukanlah usia yang sudah muda lagi. Sedangkan pegawai outsourcing masih terhitung ke dalam usia yang masih muda yaitu antara 19 tahun hingga 30 tahun. Mereka para pegawai tetap membutuhkan para pegawai outsourcing untuk membantu pekerjaannya, khususnya pekerjaan lapangan yang membutuhkan tenaga yang ekstra.

Peraturan kontrak kerja diatur dalam Kesepakatan Kerja Waktu Tertentu antara PT. PLN (PERSERO) UPJ Baleendah dengan PT. Outsourcing bahwa selama pegawai outsourcing bekerja sesuai dengan pekerjaan yang sudah ditentukan dalam kontrak kerja maka yang akan memberikan gaji adalah PT. Outsourcing, lamanya bekerja 5 hari/minggu (senin-jumat) dan 8 jam/hari. Namun, jika ada pekerjaan tambahan maka itu merupakan tanggung jawab PT. PLN (PERSERO) UPJ Baleendah dalam memberikan gaji lembur.

Secara umum, pegawai outsourcing jarang sekali mendapatkan kepuasan kerja dikarenakan kepuasan kerja yang terkikis. Namun, kenyataan yang terjadi di PT. PLN (PERSERO) UPJ Baleendah justru sebaliknya. Para pegawai outsourcing PT. PLN (PERSERO) UPJ Baleendah tidak ikut serta melakukan demonstrasi menolak adanya sistem outsourcing, me- 
reka justru sangat terbantu dengan adanya sistem ini dan mendapatkan kepuasan kerja.

Berdasarkan narasumber PT. PLN (PERSERO) UPJ Baleendah, pegawai outsourcing pada umumnya menerima gaji dari PT. Outsourcing yang menaunginya antara 1,2 juta-2 juta rupiah/bulan tanpa diberikan fasilitas dan tunjangan lainnya. Mayoritas pegawai outsourcing merasa cukup puas dengan penghasilan sebesar itu. Ada hal yang cukup menarik saat peneliti melakukan wawancara, ada salah satu pegawai lebih mempertahankan menjadi pegawai outsourcing di PT PLN (PERSERO) UPJ Baleendah dibandingkan bekerja di salah satu perusahaan swasta.

Kita sebut saja S, di perusahaan swasta lain ia akan diangkat sebagai pegawai tetap. Akan tetapi, S merasa sudah cukup puas bekerja di PT. PLN walaupun hanya sebagai pegawai outsourcing. S bekerja di bagian lapangan, bersama teman-teman yang lainnya $\mathrm{S}$ terkadang mendapatkan pekerjaan tambahan yang diberikan PT. PLN walaupun waktunya tidak menentu. Gaji tetap S diperkirakan 1,2 juta rupiah tiap bulan dan mendapat insentif sekitar 600 ribu rupiah setiap ada pekerjaan tambahan. Hal itu menjadi salah satu alasan untuk tetap bekerja sebagai pegawai outsourcing di PT PLN (PERSERO) UPJ Baleendah.

Mayoritas pegawai outsourcing PT. PLN (PERSERO) UPJ Baleendah mendapatkan sikap baik dari pimpinan. Tidak jarang pimpinan memberikan reward terhadap para pegawai outsourcing yang melakukan pekerjaannya dengan baik dan tidak jarang pula memberikan saran kepada pegawai yang kurang baik dalam pekerjaannya. Sikap pimpinan seperti itu mungkin sering dianggap sepele namun kenyataannya sangat berpengaruh terhadap kepuasan kerja para pegawai. Seperti halnya yang dirasakan oleh mayoritas pegawai outsourcing.

Pimpinan bersikap demikian karena beranggapan bahwa pegawai outsourcing adalah pegawai bantuan yang harus dihormati. Agar supaya menjaga citra PT. PLN (PERSERO) UPJ Baleendah yang sudah baik di mata orangorang luar. Karena menurut pimpinan, pegawai outsourcing sama halnya dengan orang luar dikarenakan bukan pegawai tetap PT. PLN (PERSERO) UPJ Baleendah.

Berbeda dengan pegawai tetap, besarnya gaji disesuaikan dengan peringkat kerjanya. Peringkat kerja membedakan pegawai tetap dalam hal tingginya posisi atau jabatan kerja serta besarnya gaji. Semakin kecil angka peringkat semakin besar gaji yang diterima. Seperti yang kita tahu dalam lingkungan Pegawai Negeri Sipil ada klasifikasi gaji atau tingkat jabatan yang dinamakan dengan golongan. Ma ka dalam lingkungan PLN dinamakan dengan peringkat.

Pegawai tetap adalah adalah pegawai yang menerima atau memperoleh penghasilan dalam jumlah tertentu secara teratur, termasuk anggota dewan komisaris dan anggota dewan pengawas yang secara teratur terus menerus ikut mengelola kegiatan perusahaan secara langsung, serta pegawai yang bekerja berdasarkan kontrak untuk suatu jangka waktu tertentu sepanjang pegawai yang bersangkutan bekerja penuh (full time) dalam pekerjaan tersebut. (Divisi Riset Manajemen: 2008).

Sebagai patokan, peringkat kerja untuk posisi pimpinan (manajer) di PT. PLN (PERSERO) UPJ Baleendah yaitu peringkat 16 dengan besarnya gaji pokok kurang lebih 5 juta rupiah/bulan dan peringkat terendah yaitu peringkat 20 dengan besar gaji pokok sekitar 2 juta rupiah/bulan. Pegawai tetap juga mendapatkan banyak fasilitas seperti, asuransi kesehatan, JAMSOSTEK, asuransi kecelakaan, asuransi kematian, tunjangan Hari Raya, kompensasi, kenaikan gaji, dan lain-lain.

Sudah seharusnya pegawai tetap akan mendapatkan kepuasan kerja, namun kenyataannya sebagian pegawai tetap PT. PLN (PERSERO) UPJ Baleendah masih ada yang merasakan ketidakpuasan kerja. Hal ini dikarenakan kenyamanan mereka sedikit berkurang dengan sikap pimpinan PT. PLN (PERSERO) UPJ Baleendah terhadap pegawai outsourcing yang dianggap berlebihan. Selain itu juga, sedikitnya tenaga ahli yang hanya berjumlah 45 orang menyebabkan para pegawai tetap merasa sedikit disibukkan dengan pekerjaannya.

Howell dan Dipboye (Munandar, 2001) memandang kepuasan kerja sebagai hasil keseluruhan dari derajat suka atau tidak sukanya tenaga kerja terhadap beberapa aspek dari pekerjaannya. Adapula pengertian lain dari Robbins (2006) yang mendefinisikan kepuasan kerja sebagai sikap umum pekerja yang menilai perbedaan antara jumlah imbalan yang diterima dengan yang diyakininya seharusnya diterima.

Frederick Herzberg mendefinisikan kepuasan kerja sebagai perasaan atau sikap ter- 
hadap pekerjaan yang dilakukannya yang dapat dipengaruhi oleh berbagai macam faktor, baik itu faktor internal maupun faktor eksternal.

Dalam teori kepuasan kerja ada yang dinamakan dengan teori dua faktor (two factors theory) yang dikembangkan oleh Frederick Herzberg, seorang ilmuwan behavioral terkenal. Berdasarkan penelitian yang ia lakukan, Herzberg membagi situasi yang mempengaruhi sikap seseorang terhadap pekerjaannya menjadi dua faktor yaitu motivator factor dan hygiene factor.

Motivator factor adalah faktor-faktor sebagai sumber kepuasan kerja yang terdiri dari kesempatan untuk berprestasi, pengakuan, pekerjaan itu sendiri, tanggung jawab dan kesempatan untuk maju dalam pekerjaan. Dikatakan tidak adanya kondisi-kondisi ini bukan berarti membuktikan kondisi sangat tidak puas, tetapi kalau ada akan membentuk motivasi kuat yang menghasilkan prestasi kerja yang baik. Sedangkan Hygiene factors adalah faktor-faktor yang terbukti menjadi sumber kepuasan, terdiri dari kepemimpinan, gaji, hubungan interpersonal, kondisi kerja, rasa aman dan status/peraturan perusahaan.

Selain two factor theory yang dikembangkan oleh Frederick Herzberg, ada pula teori-teori kepuasan kerja lainnya yang dikembangkan oleh tokoh-tokoh psikologi, diantaranya yaitu:

Teori ketidaksesuaian (discrepancy theory). Teori ini pertama kali dipelopori oleh Porter (As'ad, 2004). Porter mendefinisikan kepuasan kerja sebagai selisih dari banyaknya sesuatu yang "seharusnya ada" dengan banyaknya "apa yang ada. Dengan demikian, orang akan merasa puas bila tidak ada perbedaan antara yang dinginkan dengan persepsinya atas kenyataan, karena batas minimum yang diinginkan telah terpenuhi.

Apabila yang didapat ternyata lebih besar daripada yang diinginkan, maka orang akan menjadi lebih puas lagi walaupun terdapat discrepancy (ketidaksesuaian), karena merupakan discrepancy yang positif. Sebaliknya makin jauh kenyataan yang dirasakan itu di bawah standar minimum sehingga menjadi negatif discrepancy, maka makin besar pula ketidakpuasan pegawai terhadap pekerjaannya (As'ad, 2004).

Teori keadilan (equity theory. Komponen utama teori ini adalah input, hasil, orang bandingan, keadilan dan ketidakadilan (Wexley dan Yukl, 2005: 131). Input adalah sesuatu ya- ng bernilai bagi pegawai yang dianggap mendukung pekerjaannya, seperti pendidikan, pengalaman, kecakapan, banyaknya usaha yang dicurahkan, jumlah jam kerja, dan peralatan atau perlengkapan pribadi yang dipergunakan untuk pekerjaannya. Hasil adalah sesuatu yang dianggap bernilai oleh pegawai yang diperoleh dari pekerjaannya, misalnya: gaji, keuntungan sampingan status, penghargaan, serta kesempatan untuk berhasil. Orang bandingan adalah orang lain, dengan siapa pegawai membandingkan rasio input-outcomes yang dimilikinya.

Bila perbandingan itu dianggapnya cukup adil, maka ia akan merasa puas. Sebaliknya, bila perbandingan itu tidak seimbang maka akan timbul ketidakpuasan. (As'ad, 2004).

Selain yang dikemukakan oleh Frederick Herzberg mengenai motivator factor dan hygiene factor, Chiselli dan Brown juga mengemukakan pendapatnya mengenai adanya faktor-faktor yang ikut menentukan kepuasan kerja (Anoraga, 2005), seperti kedudukan, pangkat jabatan, usia, jaminan finansial dan jaminan sosial, serta mutu pengawasan.

Jika dilihat dari indikator kepuasan kerja teori Herzberg yaitu tanggung jawab, kemajuan (promosi kerja), pekerjaan itu sendiri (tantangan pekerjaan), pencapaian dan pengakuan, kepemimpinan, gaji, hubungan interpersonal, kondisi kerja, rasa aman dan status/ peraturan perusahaan. Maka pegawai tetap mendapatkan kepuasan karena hampir keseluruhan indikator sudah terpenuhi hanya saja pada beberapa pegawai masih ada yang belum merasakan kepuasan dikarenakan hubungan interpersonal yang terjalin kurang baik. Namun, pada pegawai outsourcing sudah sangat terlihat kurang terpenuhinya indikator yang menyebabkan ketidakpuasan. Akan tetapi, terlihat pada sebagian besar pegawai outsourcing merasakan kepuasan kerja. Hal ini dikarenakan hubungan interpersonal dan lingkungan kerja yang nyaman dan sangat berpengaruh bagi kepuasan kerja.

Berdasarkan hal yang sudah dipaparkan jika dilihat dari teori Herzberg, gaji akan mempunyai dampak terhadap kepuasan kerjanya. Walau-pun besarnya gaji merupakan hal yang utama, namun belum tentu semakin besar gaji yang diterima semakin besar pula tingkat kepuasan kerjanya. Kepuasan kerja merupakan hal yang bersifat individual. Setiap individu mempunyai tingkat kepuasan yang berbeda- 
beda, tidak hanya bisa dilihat dari satu sisi saja. Banyak faktor lain yang mempengaruhi kepuasan kerja para pegawai.

Yang ditemukan oleh peneliti di lapangan mengenai pegawai PT. PLN (PERSERO) UPJ Baleendah yang menganggap kepuasan kerja pegawai tidak mutlak dipengaruhi oleh gaji atau tunjangan semata. Dapat dikatakan bahwa pegawai PT. PLN (PERSERO) UPJ Baleendah khususnya pegawai outsourcing yang kurang terpenuhinya motivator factor dan hygiene factor belum tentu mengalami ketidakpuasan kerja, seperti yang dijelaskan oleh Frederick Herzberg.

Pegawai outsourcing dengan minimnya kesempatan untuk maju dalam pekerjaan, rendahnya gaji, tidak ada insentif. Tetapi, mereka tetap bertahan untuk menjadi pegawai PT. PLN (PERSERO) UPJ Baleendah. Berbeda dengan pegawai tetap yang memiliki kesempatan untuk maju dalam pekerjaannya, tingginya gaji, adanya insentif dan adanya kesempatan untuk berprestasi ternyata masih merasakan kurang mendapatkan kepuasan kerja.

Jika membicarakan kepuasan kerja sudah tentu tingkat kepuasan kerja pegawai tetap sangat tinggi bila dibandingkan dengan pegawai outsourcing. Hal tersebut disebabkan oleh banyaknya perbedaan yang diterima antara kedua pegawai tersebut. Perbedaan besarnya upah adalah hal yang sedang banyak disorot oleh media, adanya diskriminasi gaji terhadap pegawai outsourcing. Pegawai outsourcing pada umumnya hanya mendapatkan upah/gaji semata atas pekerjaannya. Berbeda dengan pegawai tetap, tidak hanya mendapatkan gaji/upah semata, namun fasilitas-fasilitas lain yang dapat menunjang kepuasan kerjanya juga mereka dapatkan. (Kompas; April 2010)

Frederick Herzberg mengemukakan jika faktor-faktor kepuasan kerja terpenuhi sudah tentu merasakan kepuasan kerja. Namun, jika faktor-faktor kepuasan kurang terpenuhi belum tentu mengakibatkan ketidakpuasan kerja. Menurut Herzberg, kepuasan kerja tidak hanya dipengaruhi oleh upah/gaji semata. Hal ini dikarenakan bahwa kepuasan kerja tidak hanya dipengaruhi oleh satu atau beberapa faktor.

\section{METODE PENELITIAN}

Penelitian ini dilakukan dengan menggunakan desain penelitian komparatif. Variabel yang akan diteliti adalah kepuasan kerja dengan dua sampel indepen. Menurut Herzberg kepuasan kerja adalah perasaan atau sikap terhadap pekerjaan yang dilakukannya yang dapat dipengaruhi oleh berbagai macam faktor, baik itu faktor internal maupun faktor eksternal. Faktor internal dikenal dengan istilah hygiene factor dan faktor eksternal yaitu motivator factor.

Pegawai outsourcing yang dimaksud dalam penelitian ini adalah pegawai yang diperbantukan untuk menyelesaikan pekerjaan-pekerjaan rutin perusahaan dan tidak ada jaminan kelangsungan masa kerjanya. Pegawai outsourcing bekerja berdasarkan perjanjian kerja waktu tertentu (PKWT), yaitu perjanjian kerja antara pengusaha dan pekerja untuk mengadakan hubungan kerja dalam waktu tertentu atau untuk pekerjaan tertentu (Divisi Riset Manajemen; 2008). Pegawai Tetap adalah adalah pegawai yang menerima atau memperoleh penghasilan dalam jumlah tertentu secara teratur, terus menerus ikut mengelola kegiatan perusahaan secara langsung, serta bekerja berdasarkan kontrak untuk suatu jangka waktu tertentu sepanjang pegawai yang bersangkutan bekerja penuh (full time) dalam pekerjaan tersebut. (Divisi Riset Manajemen: 2008).

Pada penelitian ini subjek yang akan diteliti adalah pegawai PT. PLN (PERSERO) UPJ Baleendah sebanyak 120 orang yang terdiri dari 45 orang pegawai tetap dan 75 orang pegawai outsourcing. Instrumen yang digunakan untuk menjaring data mengenai kepuasan kerja adalah instrumen yang dikembangkan berdasarkan teori kepuasan kerja Herzberg.

Adapun uji statistik yang akan digunakan untuk menguji hipotesis yang diajukan adalah $U$ Mann Whitney dengan alasan bahwa kasus penelitian ini merupakan kasus dua sampel independen, yaitu sampel pegawai outsourcing dengan pegawai tetap di PT. PLN (PERSERO) Unit Pelayanan dan Jaringan Baleendah. Selain itu juga data berskala ordinal. Uji U Mann Whitney digunakan untuk melihat ada tidaknya perbedaan kepuasan kerja diantara kedua sampel pegawai. Adapun dalam pengerjaannya, uji statistik dilakukan dengan menggunakan program SPSS versi 17.

\section{HASIL DAN PEMBAHASAN}

\section{Hasil}

Berdasarkan hasil perhitungan yang diperoleh dengan derajat kepercayaan sebesar 
95\% $(\alpha=0,05)$ diketahui bahwa $\mathrm{p}>\alpha$. Hal ini memiliki arti bahwa Ho diterima dan $\mathrm{H}_{1}$ ditolak, sehingga dapat dikatakan bahwa tidak terdapat perbedaan kepuasan kerja antara pegawai outsourcing dengan pegawai tetap di PT. PLN (PERSERO) Unit Pelayanan dan Jaringan Baleendah.

Berdasarkan hasil analisis deskriptif diperoleh data mengenai jumlah pegawai tetap yang memiliki tingkat kepuasan kerja yang tinggi yang berjumlah 33 orang (73\%), sedangkan jumlah pegawai outsourcing yang memiliki tingkat kepuasan kerja yang tinggi adalah sebanyak 36 orang (48\%). Disisi lain, jumlah pegawai tetap yang memiliki tingkat kepuasan kerja yang rendah yang berjumlah 12 orang (27\%), sedangkan jumlah pegawai outsourcing yang memiliki tingkat kepuasan kerja yang rendah adalah sebanyak 39 orang (52\%). Agar lebih jelas maka dibuat tabel sebagai berikut:

Tabel Gambaran Kriteria Kategori Sampel

\begin{tabular}{ccccc}
\hline \multirow{2}{*}{ Kepuasan } & \multicolumn{3}{c}{ Status Pekerjaan } \\
\cline { 2 - 5 } Kerja & \multicolumn{2}{c}{ Tetap } & \multicolumn{3}{c}{ Outsourcing } \\
\cline { 2 - 5 } & $\Sigma$ & $\%$ & $\Sigma$ & $\%$ \\
\hline Tinggi & 33 & 73 & 36 & 48 \\
Rendah & 12 & 27 & 39 & 52 \\
$\Sigma$ & 45 & 100 & 75 & 100 \\
\hline
\end{tabular}

\section{Pembahasan}

Berdasarkan hasil perhitungan diketahui bahwa hipotesis yang diajukan dalam penelitian ini ditolak yaitu tidak terdapat perbedaan kepuasan kerja antara pegawai outsourcing dengan pegawai tetap di PT. PLN (PERSERO) Unit Pelayanan dan Jaringan Baleendah. Hasil ini menunjukkan bahwa tingkat kepuasan kerja pegawai outsourcing tidak berbeda secara signifikan dengan tingkat kepuasan kerja pegawai tetap di PT. PLN (PERSERO) Unit Pelayanan dan Jaringan Baleendah.

Mengacu pada konsep Herzberg, berdasarkan hasil analisis deskriptif diketahui bahwa terdapat beberapa aspek dalam tingkat kepuasan kerja yang berbeda antara pegawai tetap dan pegawai outsorching, diantaranya adalah tanggung jawab, kesempatan untuk maju, kepemimpinan, upah, hubungan interpersonal, kondisi kerja dan peraturan perusahaan.

Tanggung jawab. Sebagian besar pegawai tetap merasa memiliki tanggung jawab yang tinggi, sedangkan sebagian besar pegawai outsorcing merasa memiliki tanggung jawab yang rendah. Hal tersebut dapat dipahami ka- rena pegawai outsorcing dapat dengan mudah keluar dari pekerjaan dan mencari pekerjaan lain sedangkan pegawai tetap harus mempertanggungjawabkan status yang diembannya.

Kesempatan untuk maju. Dari hasil analisis diketahui bahwa semua pegawai tetap merasa memiliki kesempatan untuk maju yang tinggi dan hampir sebagian besar pegawai outsorcing merasa tidak memiliki kesempatan untuk maju. Hal tersebut dapat dipahami mengingat untuk pegawai tetap terdapat peluang untuk memperoleh promosi jabatan, sedangkan bagi pegawai outsorcing hanya ada peluang untuk menjadi pegawai tetap dengan kemungkinan yang tidak terlalu besar.

Kepemimpinan. Berdasarkan hasil analisis diketahui bahwa sebagian besar pegawai tetap merasa bahwa tingkat kepemimpinan dalam perusahaan adalah rendah. Sedangkan sebagian besar pegawai outsourcing merasa bahwa tingkat kepemimpinan dalam perusahaan adalah tinggi. Hal tersebut dapat dipahami karena bagi pegawai tetap, apalagi dengan status PNS kepemimpinan dalam perusahaan menjadi tidak begitu terasa. Berbeda dengan pegawai outsourcing yang menerima instruksi langsung dari atasan yang berstatus sebagai pegawai tetap.

Upah. Sebagian besar pegawai tetap merasa memiliki tingkat upah yang tinggi, sedangkan sebagian besar pegawai outsourcing merasa memiliki tingkat upah yang rendah. Hal tersebut dapat dipahami mengingat bagi pegawai tetap, apaliagi berstatus sepagai PNS, gaji yang mereka peroleh bukan hanya berupa gaji pokok, tetapi juga ditambah dengan berbagai tunjangan lainnya. Berbeda dengan itu, pegawai outsourcing hanya memperoleh gaji sesuai dengan apa yang telah dikerjakannya saja.

Hubungan Interpersonal. Sebagian besar pegawai tetap merasa memiliki hubungan interpersonal yang rendah, sedangkan sebagian besar pegawai outsourcing merasa memiliki hubungan interpersonal yang tinggi. Hal tersebut dapat dipahami mengingat tingkat persaingan antar pegawai pada pegawai tetap lebih tinggi bila dibanding pada pegawai outsourcing. Selain itu, pegawai outsourcing juga memiliki perasaan senasib yang lebih kuat dengan sesama pegawai outsourcing lainnya.

Kondisi Kerja. Berdasarkan hasil analisis sebagian besar pegawai tetap yang merasa memiliki kondisi kerja yang rendah lebih ba- 
nyak bila dibandingkan dengan pegawai outsourcing. Hal tersebut dapat dipahami mengingat pegawai tetap memiliki jadwal kerja yang pasti, ditambah dengan ruangan yang monoton, sedangkan pegawai outsourcing bekerja sesuai dengan penggilan serta sebagian besar bekerja di lapangan.

Peraturan Perusahaan. Sebagian besar pegawai tetap merasakan adanya peraturan yang rendah sedangkan sebagian besar pegawai outsourcing merasakan adanya peraturan perusahaan yang tinggi. Hal tersebut dapat dipahami mengingat pegawai outsourcing adalah pegawai yang dapat dengan mudah diberhentikan atau tidak diminta untuk bekerja lagi. Berbeda dengan itu, bagi pegawai tetap, apalagi berstatus sebagai PNS, perusahaan memiliki kewajiban lain apabila harus memberhentikan pegawai.

Tidak adanya perbedaan kepuasan kerja antara pegawai tetap dan pegawai outsorching secara umum memiliki arti bahwa status pekerjaan bukan merupakan penyebab utama dari tinggi rendahnya kepuasan kerja akan tetapi mungkin saja tinggi rendahnya kepuasan kerja yang dialami oleh para pegawai tersebut disebabkan oleh faktor lain. Seperti yang diungkapkan oleh Chiselli dan Brown (dalam Anoraga, 2005) bahwa terdapat beberapa faktor lain yang berpengaruh terhadap kepuasan kerja seperti kedudukan, pangkat jabatan, usia, jaminan finansial dan jaminan sosial, serta mutu pengawasan.

Kedudukan. Meskipun hasil analisis inferensial menunjukkan bahwa tidak terdapat perbedaan yang signifikan kepuasan kerja pegawai tetap dengan pegawai outsourcing, tetapi dari hasil analisis deskriptif diketahui bahwa jumlah pegawai tetap yang memiliki tingkat kepuasan kerja yang tinggi lebih banyak bila dibanding dengan jumlah pegawai tetap yang memiliki tingkat kepuasan kerja yang rendah.

Tingginya tingkat kepuasan kerja pegawai tetap dibanding dengan pegawai outsourcing disebabkan oleh banyaknya perbedaan yang diterima antara kedua pegawai tersebut berdasarkan kedudukannya. Pegawai outsourcing pada umumnya hanya mendapatkan upah/ gaji semata atas pekerjaannya. Berbeda dengan pegawai tetap, tidak hanya mendapatkan gaji/ upah semata, namun fasilitas-fasilitas dan tun jangan lain yang dapat menunjang kepuasan kerjanya juga mereka dapatkan.
Pangkat jabatan. Hasil analisis deskriptif juga menunjukkan bahwa perbandingan jumlah pegawai outsourcing yang memiliki tingkat kepuasan kerja yang tinggi tidak berbeda jauh dengan jumlah pegawai outsourcing yang memiliki tingkat kepuasan kerja yang rendah. Setelah dilakukan interview lanjutan ternyata hal tersebut menjadi rasional mengingat pegawai outsourcing terbagi kedalam dua kelompok pegawai yaitu pegawai lapangan serta pegawai admin. Berbeda dengan pegawai lapangan yang menerima upah tambahan selain gaji pokok pegawai admin hanya memperoleh gaji pokok saja, sehingga tingkat kepuasan kerjanya menjadi rendah. Sedangkan pegawai outsourcing yang bekerja di lapangan merasakan kepuasan kerja yang tinggi karena selain mendapat gaji pokok dan uang tambahan, terkadang mereka juga mendapatkan uang tip dari konsumen.

Usia. Berdasarkan tingkatan usia, para pegawai tetap di PT. PLN (persero) Unit Pelayanan dan Jaringan Baleendah memiliki rentang usia yang beragam, namun sebagian besar berada pada rentang $30-45$ tahun. Rentang usia ini merupakan rentang usia produktif pertengahan. Faktor usia ini dapat menjadi satu kendala apabila mereka merencanakan untuk pindah ke perusahaan yang lain. Hal tersebut menjadi alasan bagi sebagian pegawai untuk merasakan tingkat kepuasan yang cukup tinggi dalam bekerja.

Di sisi lain, para pegawai outsourcing berada pada rentang usia $25-30$ tahun. Selain itu kebanyakan para pegawai outsourcing ini masih memiliki status fresh graduate yang memang membutuhkan pengalaman kerja. Karenanya para pegawai outsourcing tersebut masih memiliki peluang untuk mencari pekerjaan yang dianggap lebih memuaskan.

Jaminan finansial dan jaminan sosial. Menurut Herzberg, kepuasan kerja tidak hanya dipengaruhi oleh upah/gaji semata. Hal ini dikarenakan bahwa kepuasan kerja tidak hanya dipengaruhi oleh satu atau beberapa faktor. Berdasarkan teori "keadilan dan ketidakadilan" (Wexley dan Yukl, 2005: 131). Ketika dalam suatu perusahaan terdapat orang bandingan, dimana pegawai membandingkan rasio input-outcomes yang dimilikinya dengan orang tersebut. Para pegawai outsourcing di bagian admin akan merasakan kepuasan kerja yang rendah apabila ia membandingkan upah yang diterima dengan upah yang diterima oleh pe- 
gawai tetap yang berasal dari tingkat pendidikan yang sama. Seperti yang dikemukakan oleh Porter (As'ad, 2004) bahwa kepuasan kerja adalah selisih dari banyaknya sesuatu yang "seharusnya ada" dengan banyaknya "apa yang ada. Dengan demikian, orang akan merasa puas bila tidak ada perbedaan antara yang dinginkan dengan persepsinya atas kenyataan, karena batas minimum yang diinginkan telah terpenuhi.

Apabila yang didapat ternyata lebih besar daripada yang diinginkan, maka orang akan menjadi lebih puas lagi walaupun terdapat discrepancy (ketidaksesuaian), karena merupakan discrepancy yang positif. Sebaliknya makin jauh kenyataan yang dirasakan itu di bawah standar minimum sehingga menjadi negatif discrepancy, maka makin besar pula ketidakpuasan pegawai terhadap pekerjaannya (As'ad, 2004).

\section{SIMPULAN DAN SARAN}

\section{Simpulan}

Berdasarkan hasil analisis dan pembahasan dapat ditarik simpulan bahwa tidak terdapat perbedaan tingkat kepuasan kerja yang signifikan pada pegawai outsourcing dan pegawai tetap di PT. PLN (PERSERO) Unit Pelayanan dan Jaringan Baleendah.

\section{Saran}

Berdasarkan hasil penelitian yang telah dilakukan, dengan memperhatikan keterbatasan-keterbatasan dalam penelitian ini, peneliti mengajukan saran-saran agar dapat dijadikan bahan pertimbangan sebagai berikut:

Dalam penelitian ini peneliti hanya mengambil sampel pegawai dari satu unit kerja dalam satu wilayah. Untuk mendapatkan gambaran yang lebih komprehensif peneliti menyarankan untuk mengadakan penelitian dengan populasi yang lebih luas atau mencoba mengambil populasi yang berbeda.

Untuk pihak perusahaan diharapkan untuk melakukan berbagai inovasi untuk meningkatkan tingkat kepuasan kerja pegawai seperti adanya pemberian reward, award bagi pegawai teladan atau peluang menjadi pegawai tetap bagi pegawai outsourcing.

\section{DAFTAR PUSTAKA}

Anoraga, Pandji. (2005). Psikologi Kerja. Jakarta: Rineka Cipta.

Arikunto, Suharsimi. (2006). Prosedur Penelitian Suatu Pendekatan Praktik. Jakarta: Rineka Cipta.

Azwar, Saifuddin. (2007). Metode Penelitian. Yogyakarta: Pustaka Pelajar

Azwar, Saifuddin. (2007). Reliabilitas dan Validitas. Yogyakarta: Pustaka Pelajar

Azwar, Saifuddin. (2009). Dasar-Dasar Psikometri. Yogyakarta: Pustaka Pelajar

Chandra. (2007). Outsourcing (Alih Daya) dan Pengelolaan Tenaga Kerja Pada Perusahaan; (Tinjauan Yuridis Terhadap Undang Undang Nomor 13 Tahun 2003 Tentang Ketenagakerjaan) [Online]: ht tp://jurnalhukum.blogspot.com/2007/05/ outsourcing-dan-tenaga-kerja.html.

Divisi Riset Manajemen. (2008). Outsourcing dan Pegawai Tetap [Online]: http:// www. ppm-manajemen.ac.id

Hasibuan, Malayu S.P. (2010). Manajemen Sumber Daya Manusia. Jakarta: Bumi Aksara

Indrajit, Richardus Eko dan Djokopranoto, Richardus. (2006). Proses Bisnis Outsourcing. Jakarta: Grasindo.

Kompas. (2011, 3 Mei). Pekerja "Outsourcing” Kembali Berunjuk Rasa. Kompas [Online]:http://megapolitan.kompas.com $/ \mathrm{read} / \mathrm{xml} / 2011 / 05 / 03 /$ Pekerja.Outsourci ng.Kembali.Unjuk.Rasa.

Mangkunegara, Anwar Prabu. (2010). Evaluasi Kinerja SDM. Bandung: Refika Aditama

Munandar, Ashar Sunyoto (2010). Psikologi Industri dan Organisasi. Jakarta: Universitas Indonesia

Siegel, Sidney. (1992). Statistik NonParametrik Untuk Ilmu-ilmu Sosial. Jakarta : PT. Gramedia

Sugiyono (2010). Metode Penelitian Kuantitatif, Kualitatif dan $R \& D$. Bandung: Alfabeta

Wexley, Keaneth N, dan Yuki, Gary A. (20 05). Perilaku Organisasi dan Psikologi Personalia. Jakarta: Rineka Cipta.

Winardi. (2001). Motivasi dan Pemotivasian dalam Manajemen. Jakarta: Rajawali Pers 